stenosis in these patients, ${ }^{1}$ but we found this not to be the case. Our findings accord with those of Dustan et al, who found that most patients with angiographic evidence of renal artery disease did not have hypertension. ${ }^{3}$ It could be argued that angiographic evidence of renal artery disease does not necessarily indicate a functionally important stenosis, hence the poor relation between angiographic findings and hypertension in our study. Nevertheless, evidence of renal artery stenosis probably indicates those patients at high risk of renal complications during treatment with angiotensin converting enzyme inhibitors. We believe that in patients with evidence of peripheral vascular disease angiotensin converting enzyme inhibitors should be used with caution. Consideration should be given to the possibility of underlying renal artery stenosis.

JGFC was supported by a grant from Nissan UK.

1 Roberts DH, Tsao Y, McLoughlin GA, Breckenridge A. Placebo-controlled comparison of captopril, atenolol, labetalol and pinodol in hypertension complicated by intermittent claudication. Lancet 1987 ;ii:650-3.

2 Hricik DE, Browning PJ, Kopelman R, Goorno WE, Madias NE, Dzau VJ. Captopril induced functional renal insufficiency in patients with bilateral Captopril induced functional renal insufficiency in patients with bila
renal artery stenosis in a solitary kidney. $N$ Engl f Med 1983;308:373-6.

3 Dustan HP, Humphries AW, de Wolfe VG, Page IH. Normal arterial pressure in patients with renal artery stenosis. FAMA 1964;187:138-9.

4 Shaw AB, Gopalka SK. Renal artery thrombosis caused by antihypertensive treatment. BMF 1982;285:1617.

5 Hoefnagels WHL, Thien I. Renal artery occlusion in patients with renovascular hypertension treated with captopril. $B M \mathcal{F} 1986 ; 292: 24-5$.

(Accepted 31 August 1990)

\section{Recording diastolic blood pressure in pregnancy}

\section{J Perry, B A Stewart, J Brockwell, M Khan, P Davies, D G Beevers, D M Luesley}

University Department of Medicine and Obstetrics, Dudley Road Hospital, Birmingham B18 7QH I J Perry, MRCP, Wellcome Trust training fellow B A Stewart, $\mathrm{MB}$, house officer $\mathrm{J}$ Brockwell, $\mathrm{MB}$, house officer M Khan, MB, house officer D G Beevers, MD, reader D M Luesley, MD, senior lecturer

School of Mathematics and Statistics, University of Birmingham, Birmingham P Davies, PHD, senior lecturer

Correspondence to: Dr Perry.

BrMed f 1990;301:1198
Obstetricians are guided mainly by diastolic blood pressure in diagnosing and managing hypertensive disorders in pregnancy. ${ }^{1}$ Unfortunately, there has been confuşion and uncertainty as to how diastolic pressure should be measured in pregnancy, whether it should be recorded at the point of muffling of Korotkoff sounds (phase IV) or at the point of disappearance of sounds (phase V). Interobserver variation in detecting phase $\mathrm{V}$ is less than that associated with phase IV and in subjects who are not pregnant the difference in diastolic pressure between the two phases is small. ${ }^{2}$ Accordingly, phase $\mathrm{V}$ diastolic pressure is recommended for non-obstetric practice. ${ }^{3}$ In pregnancy (as in other states characterised by increased cardiac output), however, a large difference has been reported between the onset of muffling and the disappearance of sounds, with muffling of sounds commonly heard down to zero. ${ }^{4}$ Phase IV is therefore used to record diastolic pressure. The size and the distribution of the difference in diastolic pressure between phases IV and $\mathrm{V}$ in pregnancy, however, have not been systematically measured. We therefore conducted this study.

\section{Subjects, methods, and results}

We recorded the difference in diastolic pressure between phase IV and V Korotkoff sounds in 197 women who were pregnant (mean age 25 (range 16 to 40)) and 197 control women who were not pregnant (26 (14 to 45$))$. The mean arm circumference of the pregnant women was 25.7 (range 18 to 43 ) $\mathrm{cm}$ and of the controls 24.9 (19 to 34$) \mathrm{cm}$. Arm circumference was greater than $33 \mathrm{~cm}$ (requiring a large cuff) in six pregnant women and one control. Blood pressure (mean of three recordings) was measured in the right arm with the women seated by using a Hawksley random zero sphygmomanometer. Two observers were trained to recognise the muffling and disappearance of Korotkoff sounds using a London School of Hygiene audiotape recording and a videotape recording developed in the department. The normal approximation to the binomial was used to compare proportions and Student's $t$ test to compare means when the data were parametric.

The gap between phase IV and V diastolic pressure was wider in pregnant women than in control women, but the difference between the groups was small. The median gap in the pregnant group was 2.7 (interquartile range 0.7 to $4.7 \mathrm{~mm} \mathrm{Hg}$ compared with $0.7(0.0$ to $3 \cdot 3) \mathrm{mm} \mathrm{Hg}$ in the control group. Muffling was detected in 150 pregnant women and 118 controls (table).

As expected mean (SD) blood pressure was lower in pregnant women (systolic 106 (13.9), phase IV $68(11.7)$, phase $\mathrm{V} 65(12.4) \mathrm{mm} \mathrm{Hg}$ ) than in controls (112 (13.6), $73(10 \cdot 8), 71(11 \cdot 4) \mathrm{mm} \mathrm{Hg}$; all $\mathrm{p}<0.0001)$, and mean pulse rate was higher in pregnant women than in controls $(92(15 \cdot 1) v 77(12.8)$ beats/min; $\mathrm{p}<0.0001)$. Surprisingly, the mean arm circumference in the pregnant group was significantly higher than that in the control group $(\mathrm{p}<0 \cdot 0001)$. When pregnant and control women with a phase IV-V gap $>0 \mathrm{~mm} \mathrm{Hg}$ and those with no gap were compared those with a gap $>0 \mathrm{~mm} \mathrm{Hg}$ had lower blood pressure, higher pulse rate, and greater arm circumference, though the differences were not significant. The two observers detected muffling in a similar number of women: 129 and 139.

Distribution of difference in diastolic blood pressure $(\mathrm{mm} \mathrm{Hg})$ measured at phase IV and V Korotkoff sounds among women who were and were not pregnant

\begin{tabular}{lccccc}
\hline & 0 & -2 & -5 & -10 & $>10$ \\
\hline No of pregnant women $(n=197)$ & $47^{\star}$ & 44 & 64 & 32 & 10 \\
No of control women $(n=197)$ & 79 & 55 & 42 & 19 & 2
\end{tabular}

$\star$ Difference between groups $-32 ; 95 \%$ confidence interval -14 to -50 .

\section{Comment}

Though previous studies have described the distribution of diastolic pressure in phase IV and $\mathrm{V}$ in pregnancy ${ }^{4}$ this is the first study designed specifically to compare the interphase gap in women who were and were not pregnant. The data suggest that the gap between fourth and fifth phase diastolic pressure in pregnancy is somewhat wider on average than in the non-pregnant state, though the gap's size has been overestimated in previous reports. The principle justification for measuring phase IV diastolic pressure in obstetric practice is the belief that in many pregnant women phase IV is audible to zero and phase $\mathrm{V}$ is not detected. Our study does not support this view.

Assuming that this finding is replicated, we suggest that adopting phase $\mathrm{V}$ diastolic pressure in obstetric practice merits consideration.

We thank the midwifery staff of the antenatal clinic at Dudley Road Hospital for their help and cooperation.

\footnotetext{
1. Davey DA, MacGillivray $I$. The classification and definition of the hypertensive disorders of pregnancy. Am f Obstet Gynecol 1988;158:892-8.

2 Folsom AR, Prineas RJ, Jacobs DR, Luepker RV, Gillum RF. Measured differences between fourth and fifth phase diastolic blood pressures in 4885 adults: implications for blood pressure surveys. Int $\mathcal{F}$ Epidemio 1984;13:436-41.

3 Kirkendall WM, Feinleib M, Freis ED, Mark AL. American Heart Association recommendations for human blood pressure determination by sphygmomanometers. Circulation 1980;62:1146-55A.

MacGillivray I, Rose GA, Rowe B. Blood pressure survey in pregnancy. Clin Sci 1969;37:395-407.
}

(Accepted 25 fuly 1990) 